illustrations of the varieties given it will be seen that there is a fertile field for intelligent surgical interference, based on accurate diagnosis.

$$
\text { ( } T_{0} \text { be continued.) }
$$

\section{PRIVATE DISPOSAL OF HOUSEHOLD GARBAGE.}

\section{BY D. H. GALlOWAY, PH.G., M.D.} ciricago.

One of the first problems which engaged my attention on taking charge of Dr. Bayard Holmes' Private Hospital, was the disposal of hospital and kitchen refuse.

It was imperative that soiled dressings should not be put with other garbage to be hauled about the city and be handled by many persons. Even throwing them into a metallic vessel, to be carried from room to room and to be handled at least once more when the vessel was to be emptied, was repugnant to me. That ever-present article-at once a nuisance and of unlimited usefulness-the old newspaper, seemed to be "indicated."

When a soiled dressing was removed from a wound it is was immediately rolled up in a newspaper and put into a receptacle provided for the purpose. When the morning dressings were all done these small packages were made into large ones with more paper, and in this way conveyed to the furnace room. All repulsiveness and danger were thus obviated. This led me to contrive a way to dispose of all hospital and household refuse which has been in use in this hospital, with perfect satisfaction ever since. It is simple, inexpensive and effective.

I require that all garbage of whatever kind be wrapped into packages with newspaper or other paper as the butcher wraps up a steak. Tin cans and other non-combustible material, of course, not included. A wire basket drains as dry as possible all garbage containg water. When the furnace is not in use it is prepared by closing all registers as well as dampers in hot air pipes, and opening all drafts. A small amount of kindling is put in the furnace and on this the packages are piled. When the furnace is full the kindling is ignited and it is left to itself. Next day the furnace will be found empty except for a small quantity of fine ashes. Even melon, lemon and orange rinds, cobs and husks of green corm, potato parings, coffee grounds, etc., are completely disposed of in this way. Sometimes I have found it necessary to. light a newspaper on top of the garbage in order to start a draft up the chimney, but ordinarily there is no trouble, little heat, no odor and no smoke is noticed about the building. This applies to the summer when the furnace is not in use. I found it a little more difficult in winter, and once I thought I should be obliged to give it up. After some trials, however, I found the following method entirely satisfactory. In the morning all drafts are opened, the fire is shaken down and fresh coal put on, then the packages of garbage are put in on top of the coal. After ten or fifteen minutes the drafts are arranged as they would be if no garbage had been put in, and the next time the furnace needs attention the garbage has disappeared. After putting the packages in the furnace they should never be broken up or stirred with a poker. At first sight it would seem that a considerable amount of fuel would be required, but such is not the case. Our family consists of from twelve to twenty persons, and such a family will make a large amount of garbage each week; yet during the entire summer I did not use altogether a dollar's worth of kindling. Fruit baskets, berry boxes and other readily combustible material furnished most of the fuel necessary.

This method has been in use in this hospital for more than a year, and in that time absolutely not a pound of garbage has been put into the street, nothing but ashes, tin cans, broken glass and crockery. The secret is in the packages. The difference between these and loose garbage in the matter of combustibility is the same as the difference between lump coal and slack coal, the one will burn where the other will extinguish a fire. How to dispose of the garbage of cities is one of the most vexing of the great economic problems of this age. Burning is a wasteful process and dumping into lakes or water courses is disgusting and at all times a menace to the health of the community. All refuse organic matter, whether animal or vegetable, should be returned in some form to the soil as fertilizer. It is a mine of wealth wan. tonly wasted. If given an opportunity nature's laboratory would transform the nauseous stuff and return it to us in fruits and flowers and a thousand other attractive forms. The present method of disposing of this vast portion of nature's labor is a heavy draft on our inheritance which must sooner or later be stopped; unless the chemist realizes his dream of making animal food in the laboratory direct from the inorganic world.

If, however, it must be destroyed, it should be by fire and not by being piled up in great dumps to breed disease, nor thrown into water where it may be conveyed to great distances spreading pestilence by the way. If it is to be burned, then the nearer the source of supply-the household-the less offense and expense will it cause. It is produced in greater or less quantity by every family, but how few exercise any care about its disposal. It is carried into the street or alley, thrown into a wooden box and then left to stew and rot and stink until the scavenger comes along and gathers it up. Even then the offense is not removed for the box continues to emit foul odors and is a culture ground for all sorts of disease-producing germs. Waste paper is one kind of garbage which every one ought to be able to dispose of without throwing it into the street. Yet I have literally seen hundreds of newspapers and pieces of wrapping paper from dry goods stores, groceries, and meat markets, the last covered with grease and flies, piled about a large flat-building so that if one had set fire to the rubbish it would have seriously menaced the building. The tenants in such buildings, using steam heat and gas ranges, have no facilities for burning even waste paper, but there is always a furnace in the basement and provision should be made for conveying to the furnace and there burning it. Many of the tenants of these large buildings make a practice of throwing all waste paper out of the windows. This practice is an offense to the rest of the community and should not be tolerated. A few arrests with a nominal fine of a dollar and costs, and due notice of such arrest and fine in the daily papers, would greatly stimulate a healthy public sentiment against the practice of throwing rubbish into the street.

One very windy day I saw a woman sweep out of a vacated store enough waste paper to make a good- 
sized wagon load, and this paper littered the street for a mile in the time it took me to ride that distance on a bicycle.

A most provoking, because unnecessary, nuisance is the rubbish brought by the wind and deposited in dooryards and passageways. Every householder who has any regard for the appearance of his lawns must gather up this litter two or three times a day, and only the person who gathers it up can form any conception of its great quantity. The man who deliberately throws upon the street something which he knows another must go straightway and pick up, exhibits a selfish disregard of the rights of others which is evidence of moral degeneration or arrested development. There is one other thing to which I wish to call attention. Horses are driven about the streets dropping filth which is dried in the sun, powdered by passing vehicles and blown by the wind into our mouths and nostrils, onto our tables and into our food. Why not require that every horse carry, attached to its harness, a receptacle into which the dung would fall? Such a thing could be of leather and not overly conspicuous. Would this not be cheaper, to say nothing of the other considerations than to hire an army of men to go about and gather it up? No doubt this. will bring an incredulous smile to the face of many a reader. People are prone to submit to anything, no matter how disgusting or dangerous, if it is time-honored. There is a feeling that because an evil has not been corrected it can not be corrected. A few years ago the bicycie was considered an interloper upon the streets which were held sacred to the horse. In a few more years I expect to see the tables turned by the bicycle and other machines for locomotion and transportation, and then the man who drives a horse will be compelled to take some such precautions as mentioned or be confined to certain streets or alleys.

2639 th Street.

\section{CEREBRAL LOCALIZATION IN THE LIGHT OF RECENT HISTOLOGIC RESEARCHES. \\ BY CHARLES K. MILLS, M.D. PHILADELPHIA.}

A year or two ago, we were inclined to think that the subject of cerebral localization had been practi. cally settled, and that we were not likely to get much new light upon mooted questions.

Recent histologic investigations-brought together in a valuable paper in Brain, by Andriezen, which paper also contains much original work-have divided and subdivided the cortex into new layers and sublayers, and have determined and traced the constituents of these layers in a manner which a few years ago would have seemed utterly impossible. The resulting generally accepted histologic subdivision of the cortex is into four layers-the molecular ambiguous, great pyramidal and polymorphic. The molecular layer, which is the most superficial cortical strip, has been subdivided into strata, and more than a dozen cell and fiber systems have been traced to it and within it. Practically, the standpoint which I have always taken with reference to the question of sensory and motor localization, is that which is still held by Bechterew, Ferrier and others; namely, that just as we have separate auditory, vis. ual, gustatory, olfactory and motor zones, so we have a separate cortical localization for what is sometimes termed common sensibility; in other words, for the representation of such cutaneous and muscular sensations as touch, pain, temperature, pressure, and the location of a limb or part.

According to Andriezen, the terminals and collaterals of the main portion of the fillet radiations, that portion which conveys cutaneous and muscular sensory excitations, pass into one of the strata of the molecular layer, of the Rolandic as of other portions of the cortex, to there come into contact with the apical processes of the great pyramidal and ambiguous cells. Andriezen would therefore call these cells the first sensory cells of the cortex, no matter where they are situated. This view might therefore be regarded as making a sensori-motor region of the area around the central fissure; or rather, if carried to ite logical extreme, as making the entire cortex simply a region for the reception of sensory impressions.

For the practical purposes of the physician and surgeon, no matter what view may be taken of the nature of the processes going on in the cortex, it would seem best to still hold to the view of the separate localization of areas for the special senses, for motion, and even for muscular and cutaneous sensibility. Lesions of these areas produce phenomena of vision, audition, motion, sensation, etc., which are not produced when the lesions are situated outside of the special areas to which the functions above mentioned are assigned. The fillet radiations for cutaneous and muscular excitations, as a compact bundle, probably reach or most closely approach, the outer layer of the cortex in the postero-parietal convolutions and in the limbic lobe. Whether we should regard the cells and fibers which bring about communication between these regions and the motor cortex as true sensory terminals or as simply constituting a field of conjunction, the only cortical and subcortical lesions which will produce pure and marked sensory symptoms will be those occurring in these areas. "These incoming messages," says Andriezen, "which inform the brain of the movement of the limb, arrive (strictly speaking) not in the pre-Rolandic but in the post-Rolandic (ascending parietal) convolutions. In the preRolandic or ascending frontal convolution, and in the adjoining posterior portions of the three frontal convolutions as well as the prolongation of these areas on the mesial (marginal) convolution, we find the last term in the cortical series, the finally disposed executive mechanisms."

It would perhaps be best to define the cortical area for cutaneous and muscular sensations, as that part of the cerebrum where the fillet radiations most nearly approach the surface of the brain, before their final ramifications in the molecular layer, still holding to the old view with reference to the motor cortex. Andriezen, as already stated, speaks of the pyramidal and ambiguous cells as the first sensory cells of the cortex, because the terminals of the fillet radiations or their extensions, first touch the apical processes of these cells, and therefore these cells first receive sensory impressions from the periphery of the body. It would be better, following Forel and Nansen, to disregard entirely the subdivision into the cells of sensation and motion, and take the broad ground that we are simply dealing with the greatest and highest of sensori-motor areas, and that in the region posterior to the area usually recognized as motor, the last stage in the sensory process is reached, 